\title{
From cell line engineering to the formulated drug product: The art of manufacturing therapeutic monoclonal antibodies
}

\author{
Stefania Carrara ${ }^{1}$, Michael Ulitzka ${ }^{1}$, Julius Grzeschik² ${ }^{2}$ Henri Kornmann ${ }^{3}$, Björn Hock ${ }^{3}$, \\ and Harald Kolmar ${ }^{1}$ \\ ${ }^{1}$ Technische Universitaet Darmstadt \\ ${ }^{2}$ Ferring Darmstadt Laboratory \\ ${ }^{3}$ Ferring International Center SA
}

June 9, 2020

\begin{abstract}
Therapeutic monoclonal antibodies and related products have steadily grown to become the dominant product class within the biopharmaceutical market. Production of antibodies requires special precautions to ensure safety and efficacy of the product. In particular, minimizing antibody product heterogeneity is crucial as drug substance variants may impair the activity, efficacy, safety and pharmacokinetic properties of an antibody, consequently resulting in the failure of a product in pre-clinical and clinical development. This review will cover the manufacturing and formulation challenges and advances of therapeutic monoclonal antibodies, with a focus on improved processes to minimize variants and ensure batch-to-batch consistency. Processes put in place by regulatory agencies such as Quality-by-Design (QbD) and current Good Manufacturing Practices (cGMP) will be reviewed, and how their implementation has aided drug development in pharmaceutical companies. Advances in formulation and considerations on the intended use of a therapeutic antibody, including route of administration and patient compliance, will be discussed.
\end{abstract}

\section{INTRODUCTION TO THERAPEUTIC ANTIBODIES}

Over the past 20 years, therapeutic monoclonal antibodies (mAbs) have become increasingly important in the fight against various diseases. In several therapeutic areas such as oncology, haematology, and immunology, mAbs have become the treatment modality of choice (Lu et al., 2020). As of March 5, 2020, 93 therapeutic mAbs have been approved in the United States or Europe by the U.S. Federal Drug and Food Administration (FDA) or European Medicines Agency (EMA), respectively, of which more than one third are for the treatment of different cancers ('The Antibody Society', 2020). The first mAb approved for therapeutic use was in 1986, namely orthoclone OKT3 (Muromonab@), a murine monoclonal antibody targeting CD3, which was approved for the treatment of kidney transplantation rejection (Kung, Goldstein, Reinherz, \& Schlossman, 1979; Ribatti, 2014). The latest FDA-approved mAb is isatuximab (Sarclisa@), approved in March 2020 for the treatment of multiple myeloma by targeting CD38. As of 2018, the global $\mathrm{mAb}$ market was valued at US $\$ 115.2$ billion and is expected to continue growing at an increasing pace, reaching US $\$ 300$ billion by 2025 . Seven companies rule $87 \%$ of the market, i.e. Genentech, AbbVie, Johnson \& Johnson, Bristol-Myers Squibb, Merck Sharpe \& Dohme, Novartis and Amgen, with all other companies making up the remaining $13 \%$. Adalimumab (Humira $(\mathrm{B})$ ), targeting $\mathrm{TNF} \alpha$, has reported the highest sales figures for a biopharmaceutical in history, with nearly $\$ 20$ billion in sales in 2018 (Lu et al., 2020). Due to platform-based approaches, mAb products are easily adjusted for production and show a lower safety risk in clinical trials compared to other modalities. Thus, mAbs have become the go-to modality for first drug candidates against new targets, as they provide a rapid route for new therapeutics or proof-of-concept studies, and drive the continued growth of the mAb market (Ecker, Jones, \& Levine, 2015). 
The use and success of monoclonal antibodies for therapeutic applications is largely due to their high specificity, resulting from their complex glycoprotein structure. mAbs are immunoglobulins (Ig), of which there are 5 sub-classes: $\operatorname{IgA}, \operatorname{IgD}, \operatorname{IgE}$, IgG and $\operatorname{IgM}$, with $\operatorname{IgG}$ being the most relevant isotype for therapeutic use (Awwad \& Angkawinitwong, 2018). IgGs have a molecular weight of approximately 150,000 Daltons (Da) and are Y-shaped molecules consisting of three equal-sized parts connected with a flexible hinge. IgG molecules consist of two heavy $(\mathrm{H})$ chains, of approximately $50 \mathrm{kDa}$, and two light (L) chains, of $25 \mathrm{kDa}$. The two arms of the Y-shape end in so-called variable regions that vary between different mAbs and are responsible for antigen binding, termed the $\mathbf{f}$ ragment $\mathbf{a}$ ntigen $\mathbf{b}$ inding (Fab ) fragments. On the other hand, the stem of the Y, termed the constant region, is less variable and interacts with effector cells and molecules, commonly known as the Fc fragment (Figure 1).

With the development of hybridoma technology in 1975, Köhler and Milstein have paved the way for modern mAb technologies (Köhler \& Milstein, 1975). In addition, display technologies such as phage display (Smith, 1985) or yeast display (Boder \& Wittrup, 1998) are nowadays used for the generation of antibodies (J. K. H. Liu, 2014). Technological advances in the generation of $\mathrm{mAbs}$ are not within the scope of this review but have been recently reviewed by Lu et al. (2020). Drug discovery begins with millions of potential drug candidates. Nonetheless, resource-intensive steps, such as development of a manufacturing process are typically carried out for a single variant after extensive screening, characterization and in vitroand in vivo $\mathrm{PK} / \mathrm{PD}$ experiments and animal safety studies (Jarasch et al., 2015).

While in theory mAbs are defined by a unique primary structure of amino acids, in reality a single dose of a $\mathrm{mAb}$ product represents a plethora of variants, inherent to the biotechnological procedure used to manufacture these drug products. Heterogeneity of monoclonal antibodies comes from different sources throughout process development, but variations start at the transcriptional level through errors during gene transcription and translation. The use of protein engineering and improved manufacturability techniques can be applied to minimize mAb variants and guarantee batch-to-batch consistency. Reduction of such variants is a crucial requirement as they may impair the activity, efficacy, safety and/or pharmacokinetic properties of an antibody, ultimately resulting in the failure of a product in pre-clinical and clinical trials. Manufacturing and formulation of lead candidates are critical aspects that are often overlooked in drug discovery and early drug development. This review serves to summarize challenges and recent technological advances used to minimize $\mathrm{mAb}$ heterogeneity during the manufacturing process and improve the formulability of a drug product.

\section{MANUFACTURING OF THERAPEUTIC ANTIBODIES}

\section{Industrial Process of Manufacturing}

Optimization efforts in process development throughout the years have been devoted to decreasing process time, investment and development costs per antibody (Gronemeyer, Ditz, \& Strube, 2014). Furthermore, reducing $\mathrm{mAb}$ variants and process impurities, and delivering batch-to-batch consistency is a key deliverable of process development. The manufacturing process can be summarized into five steps (Steinmeyer \& McCormick, 2008):

1. Development of a stable and productive cell line expressing the gene of interest.

2. Cell culture conditions that allow cells to grow and produce the correct form of the desired antibody in high titres.

3. Drug substance purification.

4. Formulation steps for purification of the antibody and appropriate dosage forms (Fill \& Finish).

5. Analytical testing methods to monitor the processes and evaluate the final product.

The first two stages correspond to upstream processing (USP) operations, while the latter three are considered downstream processing (DSP) activities. Owing to the structural similarity of mAbs, platform process technologies can be developed. The platform process includes the host system for cell culture, pre-engineered vectors for transformation, pre-defined cell amplification scheme, bioreactor conditions, high performance purification systems and well-validated analytical methods (Steinmeyer \& McCormick, 2008). 
During mAb production, one of the most critical steps is the choice of a cell line. The cells must propagate well, be highly stable in culture and produce high mAb titres in its active form, meaning the protein is properly folded, glycosylated and not aggregated. Thus, based on these requirements, mammalian cells are most commonly used, as they are adapted for the production, processing and secretion of highly complex molecules (Carvalho et al., 2017). Historically, the host cell line commonly used was NS0, a murine myeloma cell line. Nonetheless, as the expression system for tissue plasminogen activator, one of the first approved biopharmaceuticals in 1986, Chinese hamster ovary (CHO) cells were used and have remained the preferred choice for production since (Kunert \& Reinhart, 2016). The preference for CHO cells is attributable to their rapid propagation and high expression titres, along with the absence of two glycan epitopes for humans, which are present in murine cell lines e.g. NS0 and Sp2/0 (Figure 1) (Gomord et al., 2010; Gronemeyer et al., 2014; Jefferis, 2009; Kelley, 2009; Kunert \& Reinhart, 2016). Other human cell lines such as human embryonic kidney (HEK) or PER.C6 cells are also considered an adequate expression host. However, reports have shown increased in vivo heterogeneity in comparison to CHO cells (Kunert \& Reinhart, 2016).

Cell line engineering and development ultimately aims at achieving higher cell titres to improve productivity and product quality. Optimisation efforts in cell medium, feed development, bioprocess development and scale-up experiments are reviewed by Gronemeyer et al. (2014). Engineering of CHO cells, for example, has resulted in cell lines capable of secreting up to $100 \mathrm{pg} /$ cell/day of humanized mAbs (Page \& Sydenham, 1991) or $80-110 \mathrm{pg} /$ cell/day of chimerized mAb (Fouser et al., 1992) in perfusion. Nevertheless, the feed method implemented has a direct influence on mAb titres. The different feed methods are batch, fed-batch or perfusion. In the batch method, all nutrients are added into the initial medium, whereas in fed-batch nutrients are added as they become depleted. Perfusion means the medium is being circulated through the growing culture while keeping the cells in the bioreactor via filtration, removing waste and supplying fresh nutrients to the cells (Dorceus et al., 2017). Fed-batch processing leads to mAb titres of 1-5 g/L, with some companies reporting up to $13 \mathrm{~g} / \mathrm{L}$ using extended culturing conditions (Kelley, 2009). The different processes have been compared in literature (Carvalho et al., 2017; Fan, Ley, \& Andersen, 2018; Kunert \& Reinhart, 2016; Ritacco, Wu, \& Khetan, 2018)

Over the years, USP operations have seen titre and stability increases and the focus has shifted to the optimization of DSP operations, focusing on improving yield, purity and productivity. After mAb production, DSP is responsible for the delivery of the active pharmaceutical ingredient (API), also referred to as bulk drug substance or drug substance (DS), to formulation and filling (Fill \& Finish). The formulated DS is then referred to as the drug product (DP) and is ready to be administered to patients. Novel technologies and the establishment of platform technologies based on Quality-by-Design (QbD) approaches has allowed developments in DSP operations. Focusing on chromatographic separations, mainly using Protein A chromatography, advances in column characteristics including higher flow rate, longer life cycles, reduced run times and increasing binding capacity has brought advances into DSP operations. However, non-chromatographic separations are of increasing interest due to the high costs associated with chromatography. Non-chromatographic separation methods include the use of membrane-based procedures, aqueous two-phase separations, precipitation or crystallization methods. These allow for high-volume feeds and rapid liquid removal, aiming at cost and process time reduction, as well as improved impurities and yield losses (Gronemeyer et al., 2014; Großhans, Wang, Fischer, \& Hubbuch, 2018; Thömmes, Twyman, \& Gottschalk, 2017). Other technologies moving away from chromatographic methods and supporting higher throughput include continuously-fed multicolumn methods using disposable columns such as simulated moving-bed chromatography. Continuous manufacturing has combined the advantages of improved process performances and flexible manufacturing (Chahar, Ravindran, \& Pisal, 2020; Großhans et al., 2018; Pollard, Brower, Abe, Lopes, \& Sinclair, 2016). Trends have led to the use of disposables, with the benefits of having lower capital investment and operational costs, increased flexibility, improved production scheduling and higher process replication (Eibl \& Eibl, 2019; Gronemeyer et al., 2014). Single-use bioreactors and technologies are applicable to Good Manufacturing Practice (GMP) regulations and are available in sizes up to 2000 L (Gronemeyer et al., 2014; Jossen, Eibl, \& Eibl, 2019; Langer \& Rader, 2019).

\section{Current GMP milestones}


Throughout the stage of development of a mAb product, production quantities differ, starting with micrograms to grams for research and toxicology studies, to tens to a few hundred grams for early-stage clinical studies, to up to hundreds of kilograms for late-stage clinicals trials and licensed production (Carson, 2005). Manufacturing facilities must therefore suit the needs and requirements of production throughout clinical development. As the resulting DP from downstream processing is ready to be administered into patients, precautions and regulations must be taken and followed to assure product quality, safety, traceability and reproducibility. Regulatory health authorities such as World Health Organization (WHO), FDA and EMA have described and constantly audit the so-called current Good Manufacturing Practices (cGMP). GMP outlines measures to ensure that processes necessary for production and testing are clearly defined, validated, reviewed and documented. By these definitions, products are ensured to be produced and controlled according to quality standards appropriate for their intended use and as required by product specification. Manufacturers and their facilities located in the European Economic Area (EEA) must hold authorization issued by a national competent authority and must comply with European Union (EU) GMP to obtain authorization. The national authorities are then responsible to inspect manufacturing sites and ensure they are effectively following the EU GMP guidelines (European Medicines Agency, 2016). The GMP guidelines are based on the following principles (WHO, 1998):

- Manufacturing facilities must maintain a clean and hygienic manufacturing area.

- Controlled environmental conditions to prevent cross-contamination of drug products from adulterants that may render the product unsafe for human consumption.

- Manufacturing processes are clearly defined and controlled. All critical processes are validated to ensure consistency and compliance with specifications.

- Manufacturing processes are controlled, and any changes to the process are evaluated. Fluctuations that affect the quality of the drug are validated as necessary.

- Cross-contamination with unlabelled major allergens is prevented.

- Records are kept (either manually or electronically) during manufacturing that demonstrate that all steps required by the defined procedures and instructions were in fact taken and that the quantity and quality of the drug was as expected. Deviations are investigated and documented accordingly.

- Records of manufacture, including distribution enable the complete history of a batch to be traced back. These records are retained in a comprehensible and accessible form.

- The distribution of drugs minimizes any risk to their quality.

- A system is available for recalling any batch from sale or supply.

- Complaints about marketed products are examined, the causes of quality defects are investigated, and appropriate measures are taken with respect to the defective products and to prevent recurrence.

With the strict implementation and control of GMP, the drug product is guaranteed to be safe and traceable. Deviations and variations can be easily tracked, and action can be taken accordingly to avoid putting the patient at risk or losing drug efficacy throughout the process.

\section{Improved manufacturability of mAb variants}

In the pharmaceutical and biotechnology industry, development programs of therapeutic mAbs are often abandoned due to poor manufacturability. Poor manufacturability of an antibody includes low expression cultures or formation of aggregates. Developability studies are now being carried out early during the process to identify any problems associated with protein stability, solubility that is insufficient to meet dosing need or sensitivity to stress. These experiments include short-term stability studies at different temperatures, freeze-thaw cycles, forced degradation studies and viscosity determination at high concentration of samples (X. Yang et al., 2013). Considering that drug substance and drug product quality attributes are affected by minimal changes in the manufacturing process, all steps may be critical to material quality and patient safety. Thus, it is mandatory to minimize and control the level of antibody variants in the drug product.

As early as translation, variants can be formed in production cell lines through the misincorporation of amino acids, such as the incorporation of serine instead of asparagine in CHO cells. While both are neutral, polar amino acids with similar physical properties, this results in the generation of a different amino 
acid sequence, a phenomenon found to be caused by starvation of a particular amino acid in cell medium (Khetan et al., 2010; Parker, Pollard, Friesen, \& Stanners, 1978; Wen et al., 2009; X. C. Yu et al., 2009). Despite this, most variants originate from post-translational modifications (PTMs) or are generated during the manufacturing process. Modifications of a drug are considered critical quality attributes (CQA), if they are linked to stability, activity, or efficacy (Jacobi et al., 2014). Major quality modifications are extensively described in literature (Jacobi et al., 2014; Sissolak, Lingg, Sommeregger, Striedner, \& Vorauer-Uhl, 2019), and glycosylation variants are commonly known to influence pharmacokinetics, antigen binding and immunogenicity (Eon-Duval, Broly, \& Gleixner, 2012; Mimura et al., 2018). A priori knowledge and glycoengineering advances of therapeutic IgG antibodies provide opportunities to optimize safety, functionality and efficacy of the drug (Sissolak et al., 2019). Examples of applying protein engineering techniques include amino acid exchanges to prevent aggregation or avoiding methionine residues in complementary-determining regions (CDRs) to prevent impactful oxidation. mAb oxidation occurs primarily on methionine residues, leading to more polar side chains by the formation of methionine sulfoxide. Additionally, replacement of $\mathrm{N}$-terminal residues by glutamine can be designed to reduce the number of charge variants arising upon pyroglutamate formation (Beck, Wurch, Bailly, \& Corvaia, 2010; Y. D. Liu, Goetze, Bass, \& Flynn, 2011). Improvements of protein sequence modifications by in silico engineering and structure-based rational design simulations have provided advancements in predicting aggregation-prone regions, stability calculations and solubility of a monoclonal antibody (Arslan, Karadag, \& Kalyoncu, 2019; Kuroda \& Tsumoto, 2020; Sormanni, Amery, Ekizoglou, Vendruscolo, \& Popovic, 2017). Furthermore, improvement of the thermodynamic stability of a monoclonal antibody can be monitored by experimental stress studies, including temperature, $\mathrm{pH}$ and protease incubations, to select molecules more resistant to aggregation (Arslan et al., 2019; Enever, PupeckaSwider, \& Sepp, 2015; Tesar et al., 2017). Monoclonal antibody structures may be altered when exposed to different temperatures, $\mathrm{pH}$ and stress conditions, causing unwanted products which may exhibit increased immunogenicity as well as reduced efficacy and activity (Cui, Cui, Chen, Li, \& Guan, 2017). Further protein engineering approaches are beyond the scope of this review and have been described elsewhere (Chiu \& Gilliland, 2016; Popplewell, 2015; C. Yang, Gao, \& Gong, 2018).

Along with protein engineering efforts, the central goal of process development of biologics is the establishment of manufacturing technologies and processes that will generate consistency in different batches (Carson, 2005). Quality-by-design (QbD) was established and first developed by Dr. Joseph M. Juran in the early 1990s, who believed that quality should be designed into a product, and that most quality crises and complications arose from the way a product was designed (Juran, 1992). Along with GMP, regulatory agencies encourage risk-based approaches and have adopted the QbD principles since early 2000s (L. X. Yu et al., 2014). By providing guidance on pharmaceutical development, QbD aims at facilitating the design of products and processes, ultimately maximizing the product's efficacy and safety profile while enhancing product manufacturability (Alt et al., 2016). The principles are described by the International Council for Harmonisation of Technical Requirements for Pharmaceuticals for Human Use (ICH) guideline documents, ICH Q8-11. The guideline documents cover: pharmaceutical development in ICH Q8, quality risk management in ICH Q9, pharmaceutical quality system in ICH Q10, and development and manufacture of drug substance in ICH Q11 (ICH ; Yu et al., 2014). The objectives of pharmaceutical QbD include: achieving meaningful product quality specifications based on clinical performance; increasing process capability and reducing product variability and defects by enhancing product and process design; facilitating the ability to identify root causes of failures; and improving product development and manufacturing efficiencies (L. X. $\mathrm{Yu}$ et al., 2014). Of the $\mathrm{QbD}$ milestones, critical quality attributes (CQA) identifies the crucial characteristics of a product required to ensure quality from a patient's perspective. By identifying specifications or numerical ranges for CQAs, candidates may be ranked and discarded accordingly (Somma, 2007). Several QbD milestones are summarized in Figure 2.

For improved manufacturability, the QbD paradigm has been incorporated into mAb-specific aspects. Karlbert et al. (2018) reported the adoption of quantitative structure-activity relationship (QSAR)-type modelling by exploiting the structural characteristics of mAbs for directed QbD implementation, increasing both product and process understanding. For upstream processes, Nagashima et al. (2013) applied the QbD 
approach to $\mathrm{mAb}$ production in $\mathrm{CHO}$ cells, focusing on quality risk management using failure mode and effects analysis. By doing so, the authors identified potential critical process parameters (CPPs) and key performance indicators (KPI) that may impact quality attributes and gained further knowledge to mitigate any future cell culture-related issues (Nagashima et al., 2013). On a scale beyond single processes, Genentech participated in a pilot program launched in 2008 by the FDA in an effort to expand the implementation of $\mathrm{QbD}$, leading to imperative improvement of $\mathrm{QbD}$ tools and concepts for subsequent products (Alt et al., 2016; Finkler \& Krummen, 2016). Today, QbD activities are fully integrated into product development phases and have led to more robust, productive manufacturing processes with increased clinical efficiency (Gronemeyer et al., 2014). A recent report has also demonstrated the efficient implementation and feasibility of using QbD-based similarity assessment of a biosimilar mAb, using an adalimumab biosimilar to Humira (B) (Zhang et al., 2020).

\section{FORMULATION DEVELOPMENT}

Compared to small molecules, biopharmaceutical drugs such as mAbs offer high specificity and potency, arising from their macromolecular structure. However, their structural complexity is the cause for challenges in formulation and delivery of mAb drugs (Mitragotri, Burke, \& Langer, 2014). Formulability is defined as the suitability of a drug product to be formulated in a way appropriate for the desired route of administration (RoA) or delivery method. Its quality attributes include, but are not limited to, solubility, stability, viscosity and aggregation. Early formulability assessment is an important aspect in the development program of any new biopharmaceutical and is often not emphasized enough (Zurdo, 2013). In line with the QbD paradigm, the intended use of an antibody is considered in the target product profile (TPP), usually during early stages of drug development. By completing a TPP, considerations into RoA, dosage form, bioavailability and stability can be addressed in early stages (Figure 2). Ultimately, every single aspect of development that affects the efficacy, cost or simplicity of an antibody can become the difference between success and failure of a drug (Zurdo, 2013).

\section{Route of Administration (RoA)}

For pharmaceutical products, the preferred RoA is generally through oral administration (non-parental) due to increased safety, good patient compliance, ease of ingestion and cost-effectiveness. However, the pitfall of macromolecular biopharmaceuticals is their limited bioavailability of only $1-2 \%$ by oral administration due to limited penetration across the intestinal epithelium, and increased susceptibility to enzymatic degradation in the intestinal lumen (Ovacik \& Lin, 2018; Zhao, Ji, Li, Roy, \& Sahajwalla, 2013). In recent years, therapeutic antibodies with diverse RoA have been approved for treatment of diseases. The most common RoA for mAbs are intravenous (IV), intramuscular (IM), or subcutaneous (SC) administrations, with injections being the principal source of delivery (Table 1) (Zurdo, 2013). Other administration methods, e.g. ocular delivery, also exist for site-specific drug administration and lowering of side effects by localized therapy (Homayun, Lin, \& Choi, 2019; Mandal et al., 2018). When compared to SC or IV, IM administration is not the ideal route of administration for mAbs due to low bioavailability (Homayun et al., 2019). IV administration is generally used for mAbs, whereas IM injections are most commonly used for vaccines (Mitragotri et al., 2014). Compared to other parental RoAs, SC injections are the most convenient as they facilitate patient self-administration and are the least invasive (Mitragotri et al., 2014; Zurdo, 2013). Despite that however, SC formulations place considerable constrains in terms of stability, aggregation and viscosity due to the need of high concentrated doses in low injection volumes (Viola et al., 2018; Zurdo, 2013).

Table 1 : Characteristics of different route of administration (RoA) for monoclonal antibodies. Data gathered from Ortega et al. (2014), Ryman \& Meibohm (2017) and Zhao et al. (2013).

\begin{tabular}{lll}
\hline RoA: & Intravenous $(\mathrm{IV})$ & Subcutaneous (SC \\
\hline Delivery frequency & Low frequency & High frequency \\
Delivery time & Hours & Seconds \\
Absorption & Fast absorption $\left(\mathrm{T}_{\max }\right.$ 0.5-4 hours) & Slow absorption \\
\end{tabular}




\begin{tabular}{lll}
\hline RoA: & Intravenous (IV) & Subcutaneous (SC \\
\hline Bioavailability & $100 \%$ & $\sim 65 \%$ \\
Half-Life & Similar for all routes & Similar for all rou \\
Dose & Low & High \\
Concentration & Diluted solutions & High concentratio \\
Volume & High injection volume & Low injection vol \\
Injection device & Saline drips, syringe & Vial and syringe, \\
Formulation for storage & Lyophilized powder for reconstitution, liquid formulations in vials or syringes & Liquid formulatio \\
Injection angle & $25^{\circ}$ & $45^{\circ}$ \\
Immunogenicity & Low & Higher ADA even \\
Patient compliance & Low (invasive, need for professional assistance) & Higher (self-admi \\
\hline
\end{tabular}

In terms of pharmacokinetics, IV appear to be superior to SC injections due to faster absorption, higher bioavailability, short time to reach maximum serum concentration $\left(\mathrm{T}_{\max }\right)$ and similar elimination half-life (Table 1) (Matucci, Vultaggio, \& Danesi, 2018). Subcutaneous route results in slow absorption, with a slow increase in plasma concentration and delayed time of $\mathrm{T}_{\max }$, ranging from 1.7 to 13.5 days (Ortega, Yancey, \& Cozens, 2014; Ryman \& Meibohm, 2017; Zhao et al., 2013). The longer $\mathrm{T}_{\text {max }}$ associated with slow lymphatic uptake is due to the limited flow rate of $1-2 \mathrm{mg} \mathrm{kg}^{-1} \mathrm{~h}^{-1}$ in the thoracic duct (Zhao, Ren, \& Wang, 2012). While the SC route offers more convenience to patients compared to IV administration, it was reported that SC administration resulted in higher risk of immunogenicity (Hamuro et al., 2017). This observation was investigated by comparing the immunogenicity profiles of marketed mAbs by monitoring the formation and persistence of anti-drug antibody (ADA) events with either SD- or IV-formulations (Hamuro et al., 2017). ADA events can potentially impact the pharmacokinetics of the product by increasing or decreasing drug clearance or affecting its pharmacodynamics and efficacy. Tocilizumab (Actemraß), a humanized $\mathrm{mAb}$ against interleukin 6 receptor (IL-6R) for the treatment of rheumatoid arthritis (RA) was studied by IV and SC RoA in a phase 3 study in a Japanese cohort. After 24 weeks of treatment, ADAs were detected in $3.5 \%$ and $0 \%$ of patients for SC or IV administration, respectively. Trastuzumab (Herceptinß), a humanized IgG1 mAb against HER2 was first approved for IV injections and became the standard treatment for patients with HER2-positive breast cancer. A SC formulation was offered as a fixed-dose alternative to the weight-adjusted IV-formulated product, and a 2-fold increase in ADA incidence was observed for SC (14.6\%) compared to IV (7.6\%) route. Rituximab (MabThera@), an anti-CD20 chimeric IgG1 approved for non-Hodgkin's lymphoma, has a similar SC formulation to trastuzumab, but no difference in ADA incidence was reported between SC and IV routes (Hamuro et al., 2017). Further examples comparing IV and SC routes for therapeutic mAbs are described in literature (Blair \& Duggan, 2018; Matucci et al., 2018). Additional examples of dosing and administration methods of FDA-approved mAbs are listed in Table 2. Despite the majority of therapeutic mAbs being administered through IV or SC routes, early drug development programs are still exploring novel delivery systems for biopharmaceuticals. Examples of these delivery systems are ones that can pass the intestinal tract without being digested, or administration through pulmonary or nasal routes (Anselmo, Gokarn, \& Mitragotri, 2019; Bequignon et al., 2019; Kumar et al., 2018; Mitragotri et al., 2014).

Table 2 : Characteristics (route of administration, mode of delivery and dose strength) of several therapeutic mAbs approved by the FDA. Abbreviations: RoA : route of administration,IV : intravenous, SC : subcutaneous, IVP : intravenous pyelogram, PFS : pre-filled syringe, AI : autoinjector. Information gathered from MedScape (2020).

\begin{tabular}{|c|c|c|c|c|c|}
\hline $\begin{array}{l}\text { INN (Trade } \\
\text { Name) }\end{array}$ & Target & Indication & RoA & Dose strength & $\begin{array}{l}\text { Mode of } \\
\text { delivery }\end{array}$ \\
\hline $\begin{array}{l}\text { Erenumab } \\
\text { (Alimovig@) }\end{array}$ & $\begin{array}{l}\text { CGRP } \\
\text { receptor }\end{array}$ & Migraines & $\mathrm{SC}$ & $\begin{array}{l}70 \text { or } 140 \\
\mathrm{mg} / \mathrm{ml}\end{array}$ & $\begin{array}{l}\text { PFS, } \\
\text { SureClick AI }\end{array}$ \\
\hline
\end{tabular}




\begin{tabular}{|c|c|c|c|c|c|}
\hline $\begin{array}{l}\text { INN (Trade } \\
\text { Name) }\end{array}$ & Target & Indication & RoA & Dose strength & $\begin{array}{l}\text { Mode of } \\
\text { delivery }\end{array}$ \\
\hline $\begin{array}{l}\text { Sarilumab } \\
(\text { Kevzara@) }\end{array}$ & IL-6 receptor & $\begin{array}{l}\text { Rheumatoid } \\
\text { arthritis }\end{array}$ & $\mathrm{SC}$ & $\begin{array}{l}150 \mathrm{mg} / 1.14 \mathrm{ml}, \\
200 \mathrm{mg} / 1.14 \mathrm{ml}\end{array}$ & $\begin{array}{l}\text { PFS, pre-filled } \\
\text { pen }\end{array}$ \\
\hline $\begin{array}{l}\text { Emicizumab } \\
(\text { Hemlibra@) }\end{array}$ & Factor IXa / X & Haemophilia A & $\mathrm{SC}$ & $\begin{array}{l}30 \mathrm{mg} / \mathrm{ml}, 150 \\
\mathrm{mg} / \mathrm{ml}\end{array}$ & $\begin{array}{l}\text { Injection, IV } \\
\text { solution vial }\end{array}$ \\
\hline 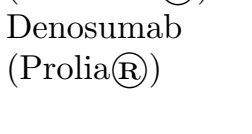 & RANK-L & $\begin{array}{l}\text { Postmenopausal } \\
\text { osteoporosis }\end{array}$ & $\mathrm{SC}$ & $\begin{array}{l}\text { Prolia: } 60 \\
\mathrm{mg} / \mathrm{ml} \mathrm{Xgeva:} \\
70 \mathrm{mg} / \mathrm{ml}\end{array}$ & PFS or vial \\
\hline $\begin{array}{l}\text { Adalimumab } \\
\text { (Humiraß) }\end{array}$ & TNF- $\alpha$ & $\begin{array}{l}\text { Rheumatoid } \\
\text { arthritis }\end{array}$ & $\mathrm{SC}$ & $\begin{array}{l}40-80 \mathrm{mg} / 0.8 \\
\mathrm{ml}\end{array}$ & $\begin{array}{l}\text { PFS, pre-filled } \\
\text { pen or vial }\end{array}$ \\
\hline $\begin{array}{l}\text { Trastuzumab } \\
\text { (Herceptin@ })\end{array}$ & HER2 & Breast cancer & $\mathrm{IV} / \mathrm{SC}$ & $\begin{array}{l}\text { IV: } 150 \\
\mathrm{mg} / \text { single-dose } \\
\text { vial, } 400 \mathrm{mg} / \\
\text { multi-dose vial } \\
\text { SC: } \\
\text { (120mg/2000units) }\end{array}$ & $\begin{array}{l}\text { IV: lyophilized } \\
\text { powder SC: } \\
\text { single-dose vial }\end{array}$ \\
\hline $\begin{array}{l}\text { Rituximab } \\
\text { (Mabthera) }\end{array}$ & CD20 & $\begin{array}{l}\text { Non-Hodgkin's } \\
\text { lymphoma }\end{array}$ & $\mathrm{IV} / \mathrm{SC}$ & $\begin{array}{l}\mathrm{IV}: 10 \mathrm{mg} / \mathrm{ml} \\
(10 \text { and } 50 \mathrm{ml} \\
\text { vials) }\end{array}$ & $\begin{array}{l}\text { Single-dose } \\
\text { vial }\end{array}$ \\
\hline $\begin{array}{l}\text { Teprotumumab } \\
\text { (Tepezza@()) }\end{array}$ & & $\begin{array}{l}\text { Thyroid eye } \\
\text { disease }\end{array}$ & IV & $\begin{array}{l}500 \\
\mathrm{mg} / \text { single-dose } \\
\text { vial }\end{array}$ & $\begin{array}{l}\text { Lyophilized } \\
\text { powder }\end{array}$ \\
\hline $\begin{array}{l}\text { Belimumab } \\
\text { (Benlysta } @ \text { ) }\end{array}$ & BLyS & $\begin{array}{l}\text { Systemic lupus } \\
\text { erythematosus }\end{array}$ & $\mathrm{IV} / \mathrm{SC}$ & $\begin{array}{l}\text { IV: } 120 \text { or } 400 \\
\mathrm{mg} / \mathrm{vial} \mathrm{SC}: 200 \\
\mathrm{mg} / \mathrm{ml}\end{array}$ & $\begin{array}{l}\text { IV: lyophilized } \\
\text { powder SC: PFS } \\
\text { or AI }\end{array}$ \\
\hline $\begin{array}{l}\text { Palivizumab } \\
\text { (Synagis@) }\end{array}$ & RSV & $\begin{array}{l}\text { Respiratory } \\
\text { syncytial virus }\end{array}$ & IM & $100 \mathrm{mg} / \mathrm{ml}$ & $\begin{array}{l}\text { Powder for } \\
\text { reconstitution } \\
\text { (injection) }\end{array}$ \\
\hline $\begin{array}{l}\text { Muromonab } \\
\text { (OKT3) } \\
\text { (discontinued) }\end{array}$ & CD3 & $\begin{array}{l}\text { Transplantation } \\
\text { rejection }\end{array}$ & IVP & $1 \mathrm{mg} / \mathrm{ml}$ & $\begin{array}{l}\text { Injectable } \\
\text { solution }\end{array}$ \\
\hline $\begin{array}{l}\text { Gemtuzumab } \\
\text { (Mylotarg@ } \mathrm{B}) \\
\text { (discontinued) }\end{array}$ & CD33 & $\begin{array}{l}\text { Acute myeloid } \\
\text { leukaemia } \\
\text { (AML) }\end{array}$ & IV & $4.5 \mathrm{mg} / \mathrm{ml}$ & $\begin{array}{l}\text { Single-dose } \\
\text { vial }\end{array}$ \\
\hline
\end{tabular}

One of the main limitations of the $\mathrm{SC}$ route is the limited dosing volume which requires high concentration of $\mathrm{mAb}$. However, advances in SC administration technologies have alleviated injection volume limitations. Higher volumes are now facilitated through the use of on-body SC delivery systems such as intradermal and patchable pumps for 5-10 ml injection volumes, and reports of novel technologies allowing volumes of 30 $\mathrm{ml}$ in self-administration SC routes are said to be feasible within the next decade (Datta-Mannan, 2019; Viola et al., 2018). The use of large volume wearable injector device (LVD) also aims at overcoming volume limitations of SC or IM injections allowing up to $10 \mathrm{ml}$ with slower rates of bolus injection (Li \& Easton, 2018).

\section{Formulation into the drug product - advances}

Formulation development is a critical aspect as the degradation of a mAb product can affect its stability and efficacy. Throughout the drug development phases, different formulations are required, and decisions on the final $\mathrm{mAb}$ formulation are made at later stages of clinical development, typically in the frame of Phase $2 \mathrm{~b}$ or Phase 3 studies. In early clinical development, IV administration is often the preferred RoA, 
especially when dose-ranging clinical studies are carried out. During early stages, the target dose is unknown, thus putting emphasis on allowing dose-flexibility by IV administration ensuring $100 \%$ bioavailability, and allowing comprehensive PK studies in humans during these critical early phase clinical trials (Li \& Easton, 2018)

Depending on the administration, different formulations will be favoured to increase product stability and ensure product quality. For IV administration, a lyophilized powder for reconstitution and further dilution is typically prepared for increased product stability. During the drying process however, this technology leads to physical stress, potentially inducing instability and degradation, leading to decreased efficacy. Today, lyophilized formulations are not preferred as they are expensive to manufacture, and it requires further dilution prior to administration. SC and injectable administrations are prepared and stored as liquid formulations in self-administration devices. The pitfall of liquid formulations however, is an increased susceptibility to physicochemical degradation and lower stability, which can impact shelf-life and product quality (Sifniotis, Cruz, Eroglu, \& Kayser, 2019). With injections being the primary delivery method for antibody products, different products exist: traditional vial and syringe (VS), pre-filled syringes (PFS), pre-filled pens, or autoinjectors (AI). While the use of PFS brings advantages such as user-friendly design and both patient and economic benefits, formulation issues arise due to solubility, aggregation and viscosity complications. The requirement for high protein concentrations of up to $200 \mathrm{mg} / \mathrm{ml}$ to achieve a therapeutic dose are thus limited by development difficulties (Li \& Easton, 2018).

Aggregation is thought to be a result of the hydrophobic areas on the surface amino acid sequence, representing the most common form of instability of protein drugs. As it decreases the available efficacious product during treatment and often leads to increased side effects and immunogenicity, aggregation is very much undesirable in a drug product (Cui et al., 2017; Giannos, Kraft, Zhao, Merkley, \& Cai, 2018). In an effort to reduce protein degradation and aggregation from high concentration formulations, excipients are added to injectable formulations, adhering to the International Pharmaceutical Excipient Council Europe (IPEC) guidelines which describe what an excipient should look like in terms of quality (Madani, Hsein, Busignies, \& Tchoreloff, 2020). Commonly used excipients include the addition of salts, amino acids or sugars to balance repulsion and attraction forces by intermediate ionic strength or by adjusting the $\mathrm{pH}$ of the solution (Kemter et al., 2018). Surfactants, such as polysorbates, are used in biologics as a stabilizing agent, but addition of such agents in high concentrations can denature proteins and cause adverse side effects such as injection site reactions (Sifniotis et al., 2019). Amino acid-based formulations containing single amino acids at high concentrations serve to stabilize and reduce viscosity (Awwad \& Angkawinitwong, 2018; Kemter et al., 2018). Hung et al. (2018) reported the improved use of concentrated proline in mAb formulations to increase stability and viscosity at $\mathrm{pH}$ 6, compared to using glycine or trehalose (Hung et al., 2018). Cryoprotectants, such as sucrose or trehalose, are commonly added to improve long-term stability as a frozen liquid and to avoid aggregation and denaturation (Cui et al., 2017). Whitaker et al. (2017) screened 56 excipients and other additives to evaluate their effect on viscosity using two different mAbs. Stability studies were performed over a 6-month period and this resulted in the ability to identify candidate high-concentration formulations with an acceptable range of viscosities. The use of excipient listings, e.g. Inactive Ingredient Search for Approved Drug Products (www.accessdata.fda.gov/scripts/cder/iig/index.cfm), provides formulation scientists with approved excipients from past formulations, avoiding extensive formulation screening experiments.

Though many mAb products are formulated in high concentration solutions, IV formulations are diluted in saline for patient administration. Ranibizumab (Lucentis $(\mathrm{B})$ ), a $\mathrm{mAb}$ approved for the treatment of agerelated macular degeneration (AMD), was prone to aggregation and loss-of-function once removed from the manufacturer's vial and diluted to low concentrations, potentially impacting its clinical outcome (Giannos et al., 2018).

High-throughput technologies for the screening of pre-formulations has allowed for the selection of candidates which are better suited for specific formulation and delivery requirements, as well as providing valuable information to improve process design and leading to increased yields and quality (Johnson, Parupudi, Wilson, \& DeLucas, 2009; Maddux, Joshi, Volkin, Ralston, \& Middaugh, 2011). Further automation tools 
for formulation development screening methods have been described (Razinkov, Treuheit, \& Becker, 2015). Further, the use of novel and developing technologies such as small-angle X-ray scattering (SAXS) together with differential scanning calorimetry (DSC), dynamic light scattering (DLS) and viscosity measurements can be used to characterize and optimize the appropriate excipient formulation for a mAb product (Xu et al., 2019). A recent review by Le Basle et al. (2020) describes further advances used to analyse the stability and physicochemical properties of mAbs. Improvements in formulation to increase the duration of action of mAbs may also be achieved through the use of hydrogels, liposomes, micelles or micro- or nanoparticles, as described in detail by Awwad \& Angkawinitwong (2018).

\section{Patient compliance}

At the core of drug development and the intended use of an antibody is patient centricity. While some formulations were developed for improved PK/PD properties or safety concerns, others were developed for increased patient compliance. The subcutaneous route has shown to be most convenient route of administration due to self-administration possibilities, with increased flexibility and potential to reduce costs for patients, payers and providers. The use of autoinjectors, PFS or mini-needles for SC administrations has led to increased patient acceptability and compliance, with the exception of potentially eliciting a higher immunological response (Datta-Mannan, 2019; Homayun et al., 2019). Using trastuzumab as an example, the re-formulated SC trastuzumab allows for administration using a hand-held syringe or single-use injection device (Jackisch et al., 2015). A study by Pivot et al. reported that $88.9 \%$ of patients treated with trastuzumab, both IV and SC, preferred administration by SC route, with "time saving" being the main reason for their preference (Pivot et al., 2014). Nevertheless, potential higher immunological ADA response, needleassociated phobia and pain, unsafe needle use and improper disposal must also be considered (Homayun et al., 2019).

Considerations for the intended use of an antibody must also be suitable for treatment of the desired disease. While parenteral administration is preferred for acute and emergency responses, non-parenteral and less invasive methods are more suitable for sustained therapy and chronic delivery (Homayun et al., 2019). Patient adherence is an important aspect in achieving successful treatment outcomes. Reports have revealed that patient adherence rates for chronic therapies in developed countries are only $50 \%$, being even lower in developing countries (Li \& Easton, 2018). Considering this, novel technologies have been developed, such as large-volume wearable injector device (LVD), allowing self-administration of a drug at a flexible time and location, with the hope of joining patient factors and promoting consistent use of a drug in chronic diseases (Li \& Easton, 2018). In an effort to increase patient compliance and reduce invasive treatments, promising advances have been reported by assessing different RoA for mAb treatment of diabetic retinopathy and potentially other chronic retinal pathologies in mice (Barcelona et al., 2018).

Special populations must also be examined, particularly if there is a certain correlation between a disease and a given population. The disease status of patients with renal or hepatic impairment, or paediatric or elderly patients will not only influence a drug's PK properties, but may also impact safety and efficacy of a drug (Mould \& Meibohm, 2016). Defining patient's physical and cognitive limitations and capabilities could also impact the ability to use a certain drug delivery device safely and effectively. Such impairments could include visual, cognitive or manual dexterity. For example, patients with rheumatoid arthritis or those eliciting involuntary hand movements due to Parkinson's disease may not be capable of using fine motor skills to control and stabilize a syringe with a narrow needle (Strochlic \& Davis, 2017). The high costs of monoclonal antibody therapy by achieving patient-convenient self-administration formulations may also hamper the success of a drug on the market (Li \& Easton, 2018). Thus, when evaluating the intended use of a therapeutic monoclonal antibody, all these attributes must be taken into consideration in order to find the balance between the needs, interests and limitations of both the patient and process development.

\section{CONCLUSION \& OUTLOOK}

The success of therapeutic monoclonal antibodies throughout the years is, in part, accredited to improvements in manufacturing and formulation allowing for the development of more efficient and cost-effective 
mAbs. Efforts to minimize mAb heterogeneity using protein engineering and the implementation of regulatory agency guidelines to ensure reproducibility, safety and traceability, such as GMP and QbD milestones discussed herein, have shown great advances in pharmaceutical and biotechnology companies. Further improvements to process development involve the implementation of single-use strategies to reduce cost and increase flexibility of platform processes. At the current rate of growth, novel computational-based approaches will become an integral part of process development and facilitate predictions of post-translational modifications, kinetic properties and pre-formulation screening, among others.

When talking about the intended use of a therapeutic antibody, it is important to note that several factors must be considered deeply in order to make adequate decisions, ranging from choosing the RoA to the drug delivery system and appropriate formulation, and even the patient population. Tuning of PK/PD properties of a monoclonal antibody not only leads to increased safety and efficacy but may facilitate increased patient acceptability and compliance, lowering of dose or dose frequency, and ultimately lead to improved therapeutic outcomes. Consideration of the TPP in early development is an important advancement in process development, as RoA, protein modifications and mAb heterogeneity may all influence the behaviour and safety of a therapeutic mAb in humans. Early pre-formulation experiments and assessments to determine which excipients are compatible and to investigate the ideal conditions for the stability of the API, e.g. temperature, $\mathrm{pH}$, etc, should be performed to improve the formulation development of a drug product.

Ultimately, the aim is to minimize potential errors and variability throughout the entire process, which could potentially hinder product quality and cause safety or efficacy concerns. While progress in the manufacturing and formulation of mAb drugs continues to be made through the advancement of high-throughput technologies and low-cost alternatives, drawbacks are nevertheless present. Compared to other drug modalities, protein pharmaceuticals tend to have higher cost of goods. Consequently, a drug product with high immunogenicity and poor bioavailability would be too costly to manufacture. Therefore, strict understanding and control of every step of the process is fundamental to the success of a therapeutic monoclonal antibody, while always keeping in mind that "the process is the product" (Kuehn, 2014).

\section{Conflicts of Interest}

The authors declare that there are no conflict of interests.

\section{REFERENCES}

Alt, N., Zhang, T. Y., Motchnik, P., Taticek, R., Quarmby, V., Schlothauer, T., .. Harris, R. J. (2016). Determination of critical quality attributes for monoclonal antibodies using quality by design principles. Biologicals , 44 (5), 291-305. https://doi.org/10.1016/j.biologicals.2016.06.005

Anselmo, A. C., Gokarn, Y., \& Mitragotri, S. (2019). Non-invasive delivery strategies for biologics. Nature Reviews Drug Discovery ,18 (1), 19-40. https://doi.org/10.1038/nrd.2018.183

Arslan, M., Karadag, D., \& Kalyoncu, S. (2019). Protein engineering approaches for antibody fragments: directed evolution and rational design approaches. Turkish Journal of Biology , 43 (1), 1-12. https://doi.org/10.3906/biy-1809-28

Awwad, S., \& Angkawinitwong, U. (2018). Overview of antibody drug delivery. Pharmaceutics , 10 (3), 1-24. https://doi.org/10.3390/pharmaceutics10030083

Barcelona, P. F., Galan, A., Nedev, H., Jian, Y., Sarunic, M. V., \& Uri Saragovi, H. (2018). The route of administration influences the therapeutic index of an anti-proNGF neutralizing $\mathrm{mAb}$ for experimental treatment of Diabetic Retinopathy. PLOS ONE , 13 (6), 1-19. https://doi.org/10.1371/journal.pone.0199079

Beck, A., Wurch, T., Bailly, C., \& Corvaia, N. (2010). Strategies and challenges for the next generation of therapeutic antibodies. Nature Reviews Immunology , 10 (5), 345-352. https://doi.org/10.1038/nri2747

Bequignon, E., Dhommée, C., Angely, C., Thomas, L., Bottier, M., Escudier, E., ... Gouilleux-Gruart, V. (2019). FcRn-Dependent transcytosis of monoclonal antibody in human nasal epithelial cells in vitro: A 
prerequisite for a new delivery route for therapy? International Journal of Molecular Sciences , 20 (6), 1379. https://doi.org/10.3390/ijms20061379

Blair, H. A., \& Duggan, S. T. (2018). Belimumab: A Review in Systemic Lupus Erythematosus. Drugs , 78 (3), 355-366. https://doi.org/10.1007/s40265-018-0872-z

Boder, E. T., \& Wittrup, K. D. (1998). Optimal screening of surface-displayed polypeptide libraries. Biotechnology Progress ,14 (1), 55-62. https://doi.org/10.1021/bp970144q

Carson, K. L. (2005). Flexibility - The guiding principle for antibody manufacturing. Nature Biotechnology , 23 (9), 1054-1058. https://doi.org/10.1038/nbt0905-1054

Carvalho, L. S., Bravim da Silva, O., Carneiro de Almeida, G., Davies de Oliveira, J., Parachin, N. S., \& Carmo, T. S. (2017). Production processes for monoclonal antibodies. Intech , $i$, 13. https://doi.org/http://dx.doi.org/10.5772/64263

Chahar, D. S., Ravindran, S., \& Pisal, S. S. (2020). Monoclonal antibody purification and its progression to commercial scale.Biologicals , 63 , 1-13. https://doi.org/10.1016/j.biologicals.2019.09.007

Chiu, M. L., \& Gilliland, G. L. (2016). Engineering antibody therapeutics. Current Opinion in Structural Biology , 38 , 163-173. https://doi.org/10.1016/j.sbi.2016.07.012

Cui, Y., Cui, P., Chen, B., Li, S., \& Guan, H. (2017). Monoclonal antibodies: formulations of marketed products and recent advances in novel delivery system. Drug Development and Industrial Pharmacy ,43 (4), 519-530. https://doi.org/10.1080/03639045.2017.1278768

Datta-Mannan, A. (2019). Mechanisms influencing the pharmacokinetics and disposition of monoclonal antibodies and peptides. Drug Metabolism and Disposition , 47 (10), 1100-1110. https://doi.org/10.1124/dmd.119.086488

Dorceus, M., Willard, S. S., Suttle, A., Han, K., Chen, P.-J., \& Sha, M. (2017). Comparing culture methods in monoclonal antibody production: Batch, fed-batch, and perfusion. Retrieved 12 April 2020, from BioProcess International website: https://bioprocessintl.com/analytical/upstream-development/comparingculture-methods-monoclonal-antibody-production-batch-fed-batch-perfusion/

Ecker, D. M., Jones, S. D., \& Levine, H. L. (2015). The therapeutic monoclonal antibody market. MAbs , 7 (1), 9-14. https://doi.org/10.4161/19420862.2015.989042

Eibl, D., \& Eibl, R. (2019). Single-use equipment in biopharmaceutical manufacture: A brief introduction. In R. Eibl \& D. Eibl (Eds.),Single-Use Technology in Biopharmaceutical Manufacture (pp. 1-11). https://doi.org/10.1002/9781119477891

Enever, C., Pupecka-Swider, M., \& Sepp, A. (2015). Stress selections on domain antibodies: 'What doesn't kill you makes you stronger'.Protein Engineering Design and Selection , 28 (3), 59-66. https://doi.org/10.1093/protein/gzu057

Eon-Duval, A., Broly, H., \& Gleixner, R. (2012). Quality attributes of recombinant therapeutic proteins: An assessment of impact on safety and efficacy as part of a quality by design development approach.Biotechnology Progress , 28 (3), 608-622. https://doi.org/10.1002/btpr.1548

European Medicines Agency. (2016). Guideline on development, production, characterisation and specification for monoclonal antibodies and related products. Guideline, 44 (July). https://doi.org/EMEA/CHMP/BWP/157653/2007

Fan, Y., Ley, D., \& Andersen, M. R. (2018). Fed-batch CHO cell culture for lab-scale antibody production . https://doi.org/10.1007/978-1-4939-7312-5_12

Finkler, C., \& Krummen, L. (2016). Introduction to the application of QbD principles for the development of monoclonal antibodies.Biologicals , 44 (5), 282-290. https://doi.org/10.1016/j.biologicals.2016.07.004 
Fouser, L. A., Swanberg, S. L., Lin, B.-Y., Benedict, M., Kelleher, K., Cumming, D. A., \& Riedel, G. E. (1992). High level expression of a chimeric anti-ganglioside GD2 antibody: Genomic kappa sequences improve expression in COS and CHO cells. Nature Biotechnology ,10 (10), 1121-1127. https://doi.org/10.1038/nbt1092-1121

Giannos, S. A., Kraft, E. R., Zhao, Z. Y., Merkley, K. H., \& Cai, J. (2018). Formulation stabilization and disaggregation of Bevacizumab, Ranibizumab and Aflibercept in dilute solutions. Pharmaceutical Research , 35 (4), 1-15. https://doi.org/10.1007/s11095-018-2368-7

Gomord, V., Fitchette, A.-C., Menu-Bouaouiche, L., Saint-Jore-Dupas, C., Plasson, C., Michaud, D., \& Faye, L. (2010). Plant-specific glycosylation patterns in the context of therapeutic protein production.Plant Biotechnology Journal , 8 (5), 564-587. https://doi.org/10.1111/j.1467-7652.2009.00497.x

Gronemeyer, P., Ditz, R., \& Strube, J. (2014). Trends in upstream and downstream process development for antibody manufacturing. Bioengineering , 1 (4), 188-212. https://doi.org/10.3390/bioengineering1040188

Grosshans, S., Wang, G., Fischer, C., \& Hubbuch, J. (2018). An integrated precipitation and ion-exchange chromatography process for antibody manufacturing: Process development strategy and continuous chromatography exploration. Journal of Chromatography A ,1533 , 66-76. https://doi.org/10.1016/j.chroma.2017.12.013

Hamuro, L., Kijanka, G., Kinderman, F., Kropshofer, H., Bu, D. xiu, Zepeda, M., \& Jawa, V. (2017). Perspectives on subcutaneous route of administration as an immunogenicity risk factor for therapeutic proteins. Journal of Pharmaceutical Sciences , 106 (10), 2946-2954. https://doi.org/10.1016/j.xphs.2017.05.030

Homayun, B., Lin, X., \& Choi, H. J. (2019). Challenges and recent progress in oral drug delivery systems for biopharmaceuticals. Pharmaceutics , 11 (3). https://doi.org/10.3390/pharmaceutics11030129

Hung, J. J., Dear, B. J., Dinin, A. K., Borwankar, A. U., Mehta, S. K., Truskett, T. T., \& Johnston, K. P. (2018). Improving viscosity and stability of a highly concentrated monoclonal antibody solution with concentrated proline. Pharmaceutical Research , 35 (7), 133. https://doi.org/10.1007/s11095-018-2398-1

ICH. (2009). ICH guidelines. Retrieved 12 April 2020, from https://www.ich.org/page/ich-guidelines

Jackisch, C., Kim, S. B., Semiglazov, V., Melichar, B., Pivot, X., Hillenbach, C., ... Ismael, G. (2015). Subcutaneous versus intravenous formulation of trastuzumab for HER2-positive early breast cancer: Updated results from the phase III HannaH study. Annals of Oncology , 26 (2), 320-325. https://doi.org/10.1093/annonc/mdu524

Jacobi, A., Enenkel, B., Garidel, P., Eckermann, C., Knappenberger, I. P., \& Kaufmann, H. (2014). Process development and manufacturing of therapeutic antibodies. In S. D. and J. M. Reichert (Ed.), Handbook of Therapeutic Antibodies (Second, pp. 601-663). Wiley-VCH Verlag GmbH \& Co.

Jarasch, A., Koll, H., Regula, J. T., Bader, M., Papadimitriou, A., \& Kettenberger, H. (2015). Developability assessment during the selection of novel therapeutic antibodies. Journal of Pharmaceutical Sciences , 104 (6), 1885-1898. https://doi.org/10.1002/jps.24430

Jefferis, R. (2009). Glycosylation as a strategy to improve antibody-based therapeutics. Nature Reviews Drug Discovery ,8 (3), 226-234. https://doi.org/10.1038/nrd2804

Johnson, D. H., Parupudi, A., Wilson, W. W., \& DeLucas, L. J. (2009). High-throughput self-interaction chromatography: Applications in protein formulation prediction. Pharmaceutical Research, 26 (2), 296-305. https://doi.org/10.1007/s11095-008-9737-6

Jossen, V., Eibl, R., \& Eibl, D. (2019). Single-use bioreactors - An overview. In R. Eibl \& D. Eibl (Eds.), Single-Use Technology in Biopharmaceutical Manufacture (pp. 37-52). https://doi.org/10.1002/9781119477891 
Juran, J. M. (1992). Departmental quality planning. National Productivity Review , 11 (3), 287-300. https://doi.org/10.1002/npr.4040110302

Karlberg, M., von Stosch, M., \& Glassey, J. (2018). Exploiting mAb structure characteristics for a directed QbD implementation in early process development. Critical Reviews in Biotechnology ,38 (6), 957-970. https://doi.org/10.1080/07388551.2017.1421899

Kelley, B. (2009). Industrialization of mAb production technology: The bioprocessing industry at a crossroads. MAbs , 1 (5), 443-452. https://doi.org/10.4161/mabs.1.5.9448

Kemter, K., Altrichter, J., Derwand, R., Kriehuber, T., Reinauer, E., \& Scholz, M. (2018). Amino acid-based advanced liquid formulation development for highly concentrated therapeutic antibodies balances physical and chemical stability and low viscosity. Biotechnology Journal , 13 (7), 1700523. https://doi.org/10.1002/biot.201700523

Khetan, A., Huang, Y., Dolnikova, J., Pederson, N. E., Wen, D., Yusuf-Makagiansar, H., ... Ryll, T. (2010). Control of misincorporation of serine for asparagine during antibody production using CHO cells. Biotechnology and Bioengineering , 107 (1), 116-123. https://doi.org/10.1002/bit.22771

Kohler, G., \& Milstein, C. (1975). Continuous cultures of fused cells secreting antibody of predefined specificity. Nature ,256 (5517), 495-497. https://doi.org/10.1038/256495a0

Kuehn, S. E. (2014). The process is the product. Retrieved 13 April 2020, from Pharmaceutical Manufacturing website: https://www.pharmamanufacturing.com/articles/2014/the-process-is-the-product/

Kumar, N. N., Lochhead, J. J., Pizzo, M. E., Nehra, G., Boroumand, S., Greene, G., \& Thorne, R. G. (2018). Delivery of immunoglobulin $G$ antibodies to the rat nervous system following intranasal administration: Distribution, dose-response, and mechanisms of delivery.Journal of Controlled Release , 286 , 467-484. https://doi.org/10.1016/j.jconrel.2018.08.006

Kunert, R., \& Reinhart, D. (2016). Advances in recombinant antibody manufacturing. Applied Microbiology and Biotechnology ,100 (8), 3451-3461. https://doi.org/10.1007/s00253-016-7388-9

Kung, P., Goldstein, G., Reinherz, E., \& Schlossman, S. (1979). Monoclonal antibodies defining distinctive human T cell surface antigens. Science, 206 (4416), 347-349. https://doi.org/10.1126/science.314668

Kuroda, D., \& Tsumoto, K. (2020). Engineering stability, viscosity, and immunogenicity of antibodies by computational design. Journal of Pharmaceutical Sciences , 109 (5), 1631-1651. https://doi.org/10.1016/j.xphs.2020.01.011

Langer, E. S., \& Rader, R. A. (2019). Biopharmaceutical manufacturing is shifting to single-use systems. Are the dinosaurs, the large stainless steel facilities, becoming extinct? American Pharmaceutical Review .

Le Basle, Y., Chennell, P., Tokhadze, N., Astier, A., \& Sautou, V. (2020). Physicochemical stability of monoclonal antibodies: A review.Journal of Pharmaceutical Sciences , 109 (1), 169-190. https://doi.org/10.1016/j.xphs.2019.08.009

Li, Z., \& Easton, R. (2018). Practical considerations in clinical strategy to support the development of injectable drug-device combination products for biologics. MAbs , 10 (1), 18-33. https://doi.org/10.1080/19420862.2017.1392424

Liu, J. K. H. (2014). The history of monoclonal antibody development - Progress, remaining challenges and future innovations. Annals of Medicine and Surgery , 3 (4), 113-116. https://doi.org/10.1016/j.amsu.2014.09.001

Liu, Y. D., Goetze, A. M., Bass, R. B., \& Flynn, G. C. (2011). N-terminal glutamate to pyroglutamate conversion in vivo for human IgG2 antibodies. Journal of Biological Chemistry , 286 (13), 11211-11217. https://doi.org/10.1074/jbc.M110.185041 
Lu, R. M., Hwang, Y. C., Liu, I. J., Lee, C. C., Tsai, H. Z., Li, H. J., \& Wu, H. C. (2020). Development of therapeutic antibodies for the treatment of diseases. Journal of Biomedical Science ,27 (1), 1-30. https://doi.org/10.1186/s12929-019-0592-z

Madani, F., Hsein, H., Busignies, V., \& Tchoreloff, P. (2020). An overview on dosage forms and formulation strategies for vaccines and antibodies oral delivery. Pharmaceutical Development and Technology , 25 (2), 133-148. https://doi.org/10.1080/10837450.2019.1689402

Maddux, N. R., Joshi, S. B., Volkin, D. B., Ralston, J. P., \& Middaugh, C. R. (2011). Multidimensional methods for the formulation of biopharmaceuticals and vaccines. Journal of Pharmaceutical Sciences , 100 (10), 4171-4197. https://doi.org/10.1002/jps.22618

Mandal, A., Pal, D., Agrahari, V., Trinh, H. M., Joseph, M., \& Mitra, A. K. (2018). Ocular delivery of proteins and peptides: Challenges and novel formulation approaches. Advanced Drug Delivery Reviews ,126 , 67-95. https://doi.org/10.1016/j.addr.2018.01.008

Matucci, A., Vultaggio, A., \& Danesi, R. (2018). The use of intravenous versus subcutaneous monoclonal antibodies in the treatment of severe asthma: A review. Respiratory Research , 19 (1), 1-10. https://doi.org/10.1186/s12931-018-0859-z

MedScape. (2020). Retrieved 11 April 2020, from https://reference.medscape.com/

Mimura, Y., Katoh, T., Saldova, R., O'Flaherty, R., Izumi, T., Mimura-Kimura, Y., .. Rudd, P. M. (2018). Glycosylation engineering of therapeutic IgG antibodies: challenges for the safety, functionality and efficacy. Protein and Cell , 9 (1), 47-62. https://doi.org/10.1007/s13238-017-0433-3

Mitragotri, S., Burke, P. A., \& Langer, R. (2014). Overcoming the challenges in administering biopharmaceuticals: Formulation and delivery strategies. Nature Reviews Drug Discovery , 13 (9), 655-672. https://doi.org/10.1038/nrd4363

Mould, D. R., \& Meibohm, B. (2016). Drug development of therapeutic monoclonal antibodies. BioDrugs , 30 (4), 275-293. https://doi.org/10.1007/s40259-016-0181-6

Nagashima, H., Watari, A., Shinoda, Y., Okamoto, H., \& Takuma, S. (2013). Application of a Quality by Design approach to the cell culture process of monoclonal antibody production, resulting in the establishment of a Design space. Journal of Pharmaceutical Sciences , 102 (12), 4274-4283. https://doi.org/10.1002/jps.23744

Ortega, H., Yancey, S., \& Cozens, S. (2014). Pharmacokinetics and absolute bioavailability of mepolizumab following administration at subcutaneous and intramuscular sites. Clinical Pharmacology in Drug Development , 3 (1), 57-62. https://doi.org/10.1002/cpdd.60

Ovacik, M., \& Lin, K. (2018). Tutorial on monoclonal antibody pharmacokinetics and its considerations in early development. Clinical and Translational Science, 11 (6), 540-552. https://doi.org/10.1111/cts.12567

Page, M. J., \& Sydenham, M. A. (1991). High level expression of the humanized monoclonal antibody CAMPATH-1H in Chinese Hamster Ovary cells.Nature Biotechnology , 9 (1), 64-68. https://doi.org/10.1038/nbt0191-64

Parker, J., Pollard, J. W., Friesen, J. D., \& Stanners, C. P. (1978). Stuttering: High-level mistranslation in animal and bacterial cells.Proceedings of the National Academy of Sciences of the United States , 75 (3), 1091-1095.

Pivot, X., Gligorov, J., Muller, V., Curigliano, G., Knoop, A., Verma, S., .. Verma, S. (2014). Patients' preferences for subcutaneous trastuzumab versus conventional intravenous infusion for the adjuvant treatment of HER2-positive early breast cancer: final analysis of 488 patients in the international, randomized, two-cohort PrefHer study. Annals of Oncology , 25 (10), 1979-1987. https://doi.org/10.1093/annonc/mdu364 
Pollard, D., Brower, M., Abe, Y., Lopes, A. G., \& Sinclair, A. (2016). Standardized economic cost modeling for next-generation mAb production. Retrieved 12 April 2020, from BioProcess International website: https://bioprocessintl.com/business/economics/standardized-economic-cost-modeling-next-generationmab-production/

Popplewell, A. G. (2015). Protein engineering: Applications to therapeutic proteins and antibodies. Pharmaceutical Sciences Encyclopedia , 1-11. https://doi.org/10.1002/9780470571224.pse537

Razinkov, V. I., Treuheit, M. J., \& Becker, G. W. (2015). Accelerated formulation development of monoclonal antibodies (MABS) and mab-based modalities: Review of methods and tools. Journal of Biomolecular Screening , 20 (4), 468-483. https://doi.org/10.1177/1087057114565593

Ribatti, D. (2014). From the discovery of monoclonal antibodies to their therapeutic application: An historical reappraisal. Immunology Letters , 161 (1), 96-99. https://doi.org/10.1016/j.imlet.2014.05.010

Ritacco, F. V., Wu, Y., \& Khetan, A. (2018). Cell culture media for recombinant protein expression in Chinese hamster ovary $(\mathrm{CHO})$ cells: History, key components, and optimization strategies.Biotechnology Progress , 34 (6), 1407-1426. https://doi.org/10.1002/btpr.2706

Ryman, J. T., \& Meibohm, B. (2017). Pharmacokinetics of monoclonal antibodies. CPT: Pharmacometrics and Systems Pharmacology ,6 (9), 576-588. https://doi.org/10.1002/psp4.12224

Sifniotis, V., Cruz, E., Eroglu, B., \& Kayser, V. (2019). Current advancements in addressing key challenges of therapeutic antibody design, manufacture, and formulation. Antibodies , 8 (2), 36. https://doi.org/10.3390/antib8020036

Sissolak, B., Lingg, N., Sommeregger, W., Striedner, G., \& Vorauer-Uhl, K. (2019). Impact of mammalian cell culture conditions on monoclonal antibody charge heterogeneity: an accessory monitoring tool for process development. Journal of Industrial Microbiology and Biotechnology , 46 (8), 1167-1178. https://doi.org/10.1007/s10295-019-02202-5

Smith, G. (1985). Filamentous fusion phage: novel expression vectors that display cloned antigens on the virion surface. Science ,228 (4705), 1315-1317. https://doi.org/10.1126/science.4001944

Somma, R. (2007). Development knowledge can increase manufacturing capability and facilitate quality by design. Journal of Pharmaceutical Innovation , 2 (3-4), 87-92. https://doi.org/10.1007/s12247-007-9017-8

Sormanni, P., Amery, L., Ekizoglou, S., Vendruscolo, M., \& Popovic, B. (2017). Rapid and accurate in silico solubility screening of a monoclonal antibody library. Scientific Reports , 7 (1), 8200. https://doi.org/10.1038/s41598-017-07800-w

Steinmeyer, D. E., \& McCormick, E. L. (2008). The art of antibody process development. Drug Discovery Today , 13 (13-14), 613-618. https://doi.org/10.1016/j.drudis.2008.04.005

Strochlic, A., \& Davis, E. (2017). Optimize combination Products: Select a drug delivery device that meets user needs. Retrieved from MedTech Intelligence website: https://www.medtechintelligence.com/feature_article/optimize-combination-products-select-drug-delivery-device-meets-user-needs/

Tesar, D., Luoma, J., Wyatt, E. A., Shi, C., Shatz, W., Hass, P. E., .. Kelley, R. F. (2017). Protein engineering to increase the potential of a therapeutic antibody Fab for long-acting delivery to the eye. MAbs , 9 (8), 1297-1305. https://doi.org/10.1080/19420862.2017.1372078

The Antibody Society. (2020). Retrieved 13 April 2020, from https://www.antibodysociety.org/home/

Thommes, J., Twyman, R. M., \& Gottschalk, U. (2017). Alternatives to packed-bed chromatography for antibody extraction and purification. In U. Gottschalk (Ed.), Process Scale Purification of Antibodies (Second Edi, pp. 215-231). John Wiley \& Sons, Inc. 
Viola, M., Sequeira, J., Seica, R., Veiga, F., Serra, J., Santos, A. C., \& Ribeiro, A. J. (2018). Subcutaneous delivery of monoclonal antibodies: How do we get there? Journal of Controlled Release ,286 (April), 301-314. https://doi.org/10.1016/j.jconrel.2018.08.001

Wen, D., Vecchi, M. M., Gu, S., Su, L., Dolnikova, J., Huang, Y.-M., ... Meier, W. (2009). Discovery and investigation of misincorporation of serine at asparagine positions in recombinant proteins expressed in Chinese Hamster Ovary cells. Journal of Biological Chemistry , 284 (47), 32686-32694. https://doi.org/10.1074/jbc.M109.059360

Whitaker, N., Xiong, J., Pace, S. E., Kumar, V., Middaugh, C. R., Joshi, S. B., \& Volkin, D. B. (2017). A formulation development approach to identify and select stable ultra-high-concentration monoclonal antibody formulations with reduced viscosities. Journal of Pharmaceutical Sciences , 106 (11), 3230-3241. https://doi.org/10.1016/j.xphs.2017.06.017

WHO. (1998). WHO good manufacturing practices for pharmaceutical products: Main principles. WhoGMP-Annex 2 , (961), 170-170 p.

Xu, Y., Wang, D., Mason, B., Rossomando, T., Li, N., Liu, D., ... Liu, H. (2019). Structure, heterogeneity and developability assessment of therapeutic antibodies. MAbs , 11 (2), 239-264. https://doi.org/10.1080/19420862.2018.1553476

Yang, C., Gao, X., \& Gong, R. (2018). Engineering of Fc fragments with optimized physicochemical properties implying improvement of clinical potentials for Fc-based therapeutics. Frontiers in Immunology, 8 . https://doi.org/10.3389/fimmu.2017.01860

Yang, X., Xu, W., Dukleska, S., Benchaar, S., Mengisen, S., Antochshuk, V., ... Ambrogelly, A. (2013). Developability studies before initiation of process development: Improving manufacturability of monoclonal antibodies. MAbs , 5 (5), 787-794. https://doi.org/10.4161/mabs.25269

Yu, L. X., Amidon, G., Khan, M. A., Hoag, S. W., Polli, J., Raju, G. K., \& Woodcock, J. (2014). Understanding pharmaceutical quality by design.AAPS Journal , 16 (4), 771-783. https://doi.org/10.1208/s12248-0149598-3

Yu, X. C., Borisov, O. V., Alvarez, M., Michels, D. A., Wang, Y. J., \& Ling, V. (2009). Identification of codon-specific serine to asparagine mistranslation in recombinant monoclonal antibodies by high-resolution mass spectrometry. Analytical Chemistry , 81 (22), 9282-9290. https://doi.org/10.1021/ac901541h

Zhang, E., Xie, L., Qin, P., Lu, L., Xu, Y., Gao, W., ... Liu, S. (2020). Quality by Design-based assessment for analytical similarity of adalimumab biosimilar HLX03 to Humira(r). The AAPS Journal ,22 (3), 69. https://doi.org/10.1208/s12248-020-00454-z

Zhao, L., Ji, P., Li, Z., Roy, P., \& Sahajwalla, C. G. (2013). The antibody drug absorption following subcutaneous or intramuscular administration and its mathematical description by coupling physiologically based absorption process with the conventional compartment pharmacokinetic model. Journal of Clinical Pharmacology , 53 (3), 314-325. https://doi.org/10.1002/jcph.4

Zhao, L., Ren, T. H., \& Wang, D. D. (2012). Clinical pharmacology considerations in biologics development. Acta Pharmacologica Sinica , 33 (11), 1339-1347. https://doi.org/10.1038/aps.2012.51

Zurdo, J. (2013). Developability assessment as an early de-risking tool for biopharmaceutical development. Pharmaceutical Bioprocessing ,1 (1), 29-50. https://doi.org/10.4155/pbp.13.3

\section{Figure Legends}

Figure 1: Overview of IgG antibodies. A) Structure of IgG showing light (L) chains and heavy $(\mathrm{H})$ chains in pink and purple, respectively. The glycan-modification position N297 is depicted with red stars. B) N-glycan structure of monoclonal antibodies in different species. Abbreviations : NeuAc: N-acetylneuraminic acid, 
Man: mannose, Fuc: fucose, GlcNAc: N-acetylglucosamine, Gal: galactose. Adapted from Gomord et al ., 2010 .

Figure 2: Summary of Quality-by-Design milestones. Taken from ICHQ11 guidelines document.

Table 1: Characteristics of different routes of administration (RoA) for monoclonal antibodies. Data gathered from Ortega et al. (2017), Ryman \& Meibohm (2017) and Zhao et al. (2013).

Table 2: Characteristics (route of administration, mode of delivery and dose strength) of several therapeutic mAbs approved by the FDA. Abbreviations: RoA: route of administration; IV: intravenous; SC: subcutaneous; IVP: intravenous pyelogram; PFS: pre-filled syringe; AI: autoinjector. Information gathered from MedScape (2020).

A)

B)
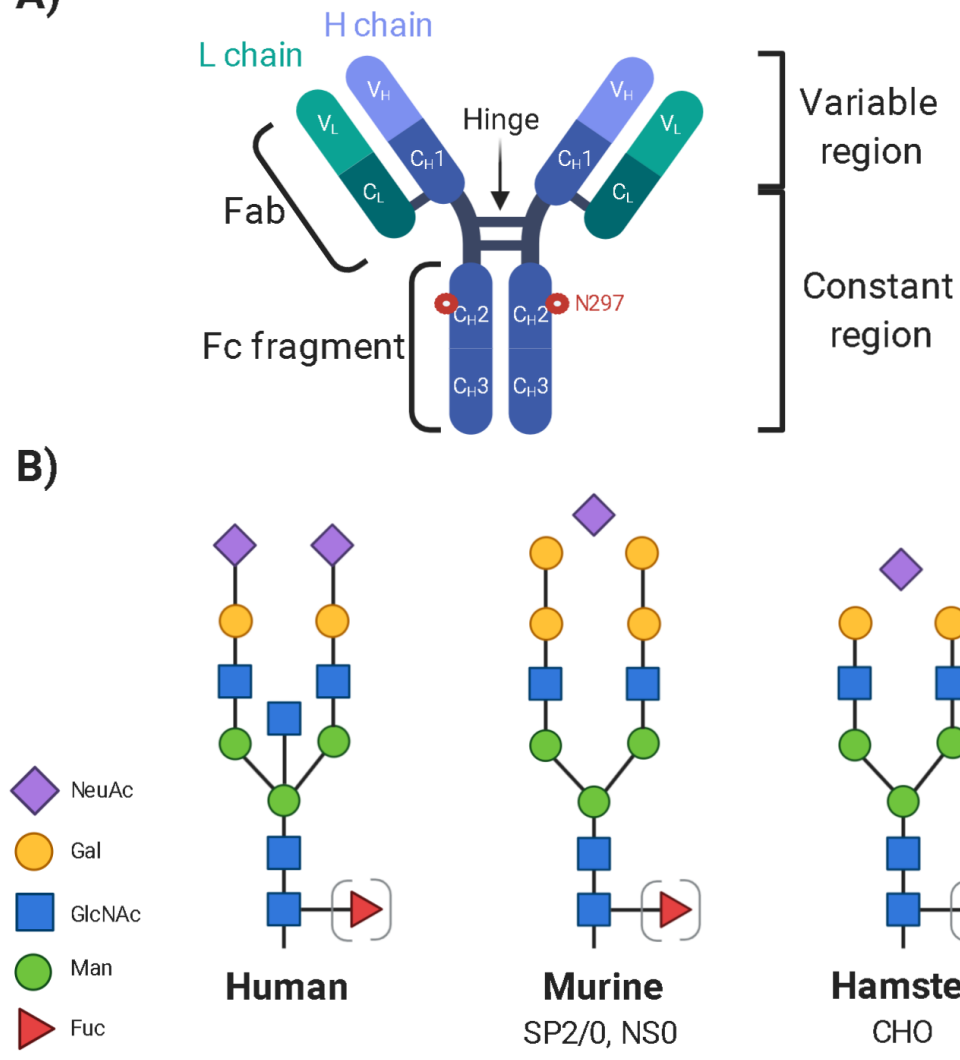

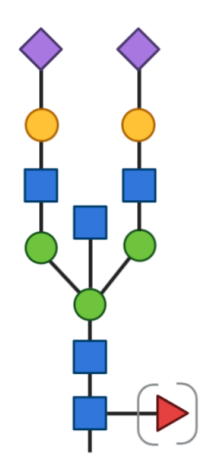

Human

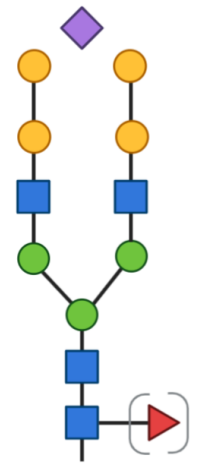

Murine SP2/0, NSO

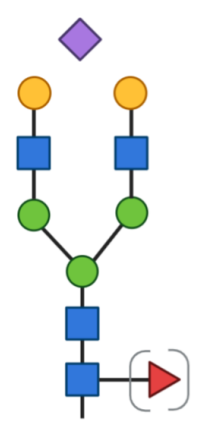

Hamster

$\mathrm{CHO}$ 
Target Product

Profile (TPP)

Quality Target

Product Profile (QTTP)

Process Risk

Assessment (PRA)

Process

Characterization

Study

\section{Design Space}

Control Strategy

Control Strategy

\begin{tabular}{|c|}
\hline Qualification \\
Studies \\
\hline $\begin{array}{c}\text { Continued Process } \\
\text { Verification } \\
\text { Studies }\end{array}$ \\
\hline
\end{tabular}

Intent of a product

- Desired features (indication, desired efficacy, safety claims, desired drug format, etc.)

- Quality characteristics of a product $\rightarrow$ Ensure desired quality when achieved (safety and efficacy) - Attributes include: route of administration (RoA), dosage form, bioavailability, strength, stability

- Identifies manufacturing parameters for each process step

- Factors that have potential to impact critical quality attributes (CQA) e.g. cell density, cell viability,

load pH or column conductivity for chromatography applications

- Examines deliberate variation of parameters identified by PRA to determine the limits of variation - Leads to classification of critical process parameters (CPP) and non-CPP, with the CPPs defined as a process parameter whose variability impact a CQA and must be controlled throughout

- Represents combination and interaction of input variables (e.g. material attributes) and process parameters that demonstrate guarantee of quality

- Description of the following based on design space and CPPs: Input Material Controls, In-process Controls, Parameter Controls, Specifications, Product Characterization, Process Monitoring

- Studies of facilities, utilities and equipment

- Process performance qualification study (PPQ) performed at full-scale in order to mimic the commercial manufacturing operation

- Demonstrate that the process validation package remains up-to-date across the lifecycle of the product - Post-marketing activities 